\section{B A Institute of \\ YK Business Administration \\ 六下 \\ Karachi \\ Leadership and Ideas for Tomorrow}

Business Review

Volume 6 Issue 1 January-June 2011

$1-1-2011$

\title{
International financial reporting standards: A cautionary note for emerging economies
}

\author{
Khursheed Omer \\ University of Houston Downtown, USA \\ Darshan Wadhwa \\ University of Houston Downtown, USA
}

Follow this and additional works at: https://ir.iba.edu.pk/businessreview

Part of the Accounting Commons, Finance and Financial Management Commons, and the International Economics Commons

\section{(c) (1)}

This work is licensed under a Creative Commons Attribution 4.0 International License.

\section{Recommended Citation}

Omer, K., \& Wadhwa, D. (2011). International financial reporting standards: A cautionary note for emerging economies. Business Review, 6(1), 9-26. Retrieved from https://doi.org/10.54784/1990-6587.1179 


\title{
ARTICLE
}

\section{International Financial Reporting Standards: A Cautionary Note for Emerging Economies ${ }^{1}$}

\author{
Khursheed Omer and Darshan Wadhwa \\ University of Houston Downtown, USA
}

\begin{abstract}
Long before the present economic crisis unfolded, the Financial Accounting Standards Board (FASB) and the International Accounting Standards Board (IASB) had been working to achieve harmonization in accounting and financial reporting standards across the globe. Now that the world economic community has become more integrated, cross border flow of capital has gained unprecedented momentum and steps are underway to achieve this goal as early as possible. Initial efforts to harmonize local accounting principles and practices with those followed in developed economies were generally aimed at facilitating foreign multinationals operating in other countries. The desired goal of harmonization now ought to be formulation of accounting standards that would facilitate optimal resource allocation for economic growth and prosperity and proper training of accountants with an informed professional outlook. Harmonization of accounting practices and procedures in emerging economies, therefore, should not be viewed as simply a process of complying with externally imposed standards. Rather, the process should involve exchange of ideas among all the participants.

For such exchange of ideas to be meaningful, a critical examination of the factors that contributed to standards of reporting financial information is necessary. Discourse on such a vast topic requires an extensive work, which is beyond the scope of this paper. However, since United States of America has been at the forefront of codifying accounting principles, this paper is selectively focused on some contentious financial reporting issues and controversies that have impeded the development of a cohesive theory governing accounting standards for measurement and reporting of enterprise performance.
\end{abstract}

\section{INTRODUCTION AND BACKGROUND}

The role of accounting in bringing on the ongoing economic crisis is a widely debated topic. Some hold accounting standards requiring fair value

An earlier version of this paper was presented in AIMS7 Conference held in Banglore,December 20--22,2009.

See Horngren (1973), May and Sundem (1976) for example of this point of veiw.

See Blough, 1955; Moonitz, 1957; Hill, 1957; Li,1961; Drinkwatwer \& Edwards, 1965; Chambers, 1968; Hawkins, 1968; Barton, 1970;

Nair \& Weygandt, 1981; and Vulkan \& Rue, 1985 for these early criticisms. 
accounting responsible for unduly distorting the health of companies' balance sheets and contributing to a negatively reinforcing downward spiral. Others argue that accountants are often scapegoats for investors' excesses as was the case in the United States in 1929 crash when accountants were accused of putting water on the balance sheet in the 1920s. Compelling arguments may be found on both sides. It is hard to pinpoint the blame for such a monumental crisis on any specific factor, nonetheless the fact remains that accounting standards of reporting financial performance play a vital role in guiding important economic decisions at the firm level.

Long before the present economic crisis unfolded, the Financial Accounting Standards Board (FASB) and the International Accounting Standards Board (IASB) had been working to achieve harmonization in accounting and financial reporting standards across the globe. Now that the world economic community has become more integrated, cross border flow of capital has gained unprecedented momentum and steps are underway to achieve this goal as early as possible. In November 2008, The Securities and Exchange Commission in US issued a proposed road map that would require U.S. public companies to convert to international financial reporting standards. (IFRS). IFRS could be mandatory as early as 2014 if certain milestones were to be met by 2011. The milestones include continued improvement of IFRS, revamping of the funding mechanism for International Accounting Standards Board (IASB) operations, and significant progress in the training of accountants and stakeholders on the IASB standards (Marden and Brackney 2009, 32)

Initially harmonization of local accounting principles and practices with those followed in developed economies was generally aimed at facilitating foreign multinationals operating in other countries. The desired goal of harmonization now ought to be formulation of accounting standards that would facilitate optimal resource allocation for economic growth and prosperity and proper training of accountants with an informed professional outlook. Harmonization of accounting practices and procedures in emerging economies, therefore, should not be viewed as simply a process of complying with externally imposed standards. Rather, the process of harmonization should involve exchange of ideas among all the participants.

For such exchange of ideas to be meaningful, a critical examination of the factors that contributed to standards of reporting financial information is necessary. Discourse on such a vast topic requires extensive work, which is beyond the scope of this paper However, since United States of America has been at the forefront of codifying accounting principles, this paper is selectively focused on some contentious financial reporting issues and controversies that have impeded the development of a cohesive theory governing accounting standards for measurement and reporting of enterprise performance. A brief historical account of the drifting 
course of establishing accounting standards for financial reporting is presented in the following section.

\section{THE INCONCLUSIVE QUEST FOR A CONCEPTUAL FRAMEWORK}

Measurement and reporting of enterprise income and financial position has been the focal point of accounting standards ever since attempts to improve and organize the discipline of accounting began in the aftermath of the Great Depression in the US. Historically, concepts of business income have evolved around two fundamental, but often competing, considerations: operational facility and usefulness. Operational facility refers not only to the practical ease in the process of measuring income but also to the logic, internal consistency, and objectivity of the method of measurement. Such basic accounting principles as realization, matching, and cost basis are examples of rules and conventions that accountants have devised exclusively to ensure operational facility and which have no real-world counterparts or any significance outside of their role in the logic of accounting literature (Hendrickson 1982, 138-139).

On the other hand, the notion of usefulness is inherent in the very idea of calculating a measure to summarize the results of operations of an enterprise. Ideally, therefore, operational facility and usefulness should not be competing goals. However, the factors that governed development of accounting techniques and procedures [realization, matching, and cost basis] and the economic factors that brought about development of securities markets resulting in widespread participation by the general public in financial activity have not always defined usefulness of accounting data in the same terms. Accordingly the quest for usefulness in reported income has for the most part been pursued along two different lines of development.

The first line of development concerns the achievement of uniformity in disclosures and a sound basis for comparability in the reported income by narrowing the areas of wide divergence in financial reporting. The first three hundred years between publications of Pacioli's Summa and the accounting practices of the nineteenth century were devoted to the refinement and diffusion of the double entry book keeping method. Up until the seventeenth century income was the byproduct of the closing process primarily due to the nature of venture trading. At the termination of each venture, profit or loss was determined by subtracting the investment from the proceeds of venture assets (Chatfield 1977, 52 \& 256-259).

Lack of a theoretical underpinning in defining income led to the adoption of a wide variety of alternate accounting practices for essentially the same types of situations by different business firms in accordance with their own preference. During the 1920's, when the general public in the United States of America first 
began buying corporate securities, auditors faced the problem of certifying financial data for distribution to general public (Chatfield 1977, 129). By this time the proliferation of accounting alternatives had reached to such alarming proportions that it became a major target of criticism in the printed media. Government intervention in the form of Securities and Exchange Acts of 1933 and 1934 and the work undertaken by the professional accounting bodies was, therefore, primarily directed towards elimination of undesirable accounting practices and codification of acceptable alternatives (Belkaoui 1981, 22-23).

The second line of development deals with the theoretical basis of the income concept that can be interpreted in terms of real-world experience and not in terms of adherence to institutional rules and guidelines. But this theoretical pursuit for a concept of income did not take hold until after World War II and is to this date in the state of transition. The advent of corporations engaged in continuous trading as opposed to venture trading and the need to pay dividends to shareholders at regular intervals necessitated periodic reckoning of the financial position of the enterprise. Consequently the need for distinction between capital and income was clearly recognized and profit was determined by measuring the increase in net assets during a period, either through a process of periodic appraisal of the asset. This approach was based on the proprietary theory, which holds that the firm is owned by some specified person or group, such as a sole proprietor, a partnership, or a number of stock holders.

At this initial stage, operational facility and usefulness remained somewhat compatible goals. However, this focus on determination of income through measurement of changes in assets shifted from the proprietary concept to the entity concept with the adoption of income tax laws and the development of publicly owned corporations in the United States of America. Under this approach, income earned by a business represented the net result of arms length transactions whereby customers paid (or committed to pay to the business amounts in excess of the cost of products sold or services rendered.

A number of causal factors were responsible for the emergence of income statement as the primal financial statement. Langenderfer (1987) identifies the work of Paton and Canning as important and Dailey (1984) asserts that the 1934, widespread ownership of stock, and the separation of ownership and management were important in making the income statement dominant. Hendriksen (1965) also identified separation of ownership and management. The more widespread ownership of joint report of the New York Stock Exchange and American Institute of Accountants resulted in increased income statement focus. Littleton and Zimmerman (1962) treated this quest for financing other than short-term credit as the primary cause of the eventual dominance of the income statement. Brown (1975) and Littleton and Zimmerman (1962) also suggested that the income tax had some 
influence on increasing the importance of the income statement, but only Chatfield (1977) promoted the income tax as primary cause of the rise to dominance of the income statement.

To facilitate determination of transaction based income, the principles of realization, uniformity, objectivity, and conservatism were established and the matching concept assumed the position of a central doctrine governing accounting practice. This led to the introduction of earnings realization approach along side the asset/liability approach. Arguments against this mechanical and legalistic approach to determine income were overshadowed by the continuing debate in professional accounting circles on the proper way to apply the realization rule for proper matching of revenues and expenses. As a consequence the revamping of accounting practice by the American Institute of Accountants during the decade of 1930's extensively dealt with matching and realization rules. The criticism, however, did lead to serious efforts on the part of both the individual researcher and the profession to find a theoretical basis for the concept of business income.

\section{THE INFLUENCE OF ECONOMIC CONCEPTS}

Economists have contributed a great deal to the understanding of income concepts. It was Adam Smith who first defined income as the amount which can be consumed without encroaching upon capital, including both fixed and circulating capital (Hendriksen 1982, 143). Hicks (1946) further expounded on this theme in his analysis of the general equilibrium of the economy and developed seven notions of the income concept. The first notion conveyed the central meaning of the concept of income and is frequently quoted as the Hicksian definition of income:

"We ought to define a man's income as the maximum value he can consume during a week, and still expect to as well of at the end of the week as he was at the beginning". (p. 172)

The form in which Hicks stated his central meaning had no operational qualities since it gave no indication of what was meant by "value" or "well off" Clarke $(1982,236-254)$. Hicks had used this core concept to simply describe elements of the notion of income. He then developed three ex ante and three ex post approximations of the central meaning to refine the core notion of income. Alexander (1950), a member of the Study Group on Business Income commissioned by the American Institute of Accountants was the first one to interpret the Hicksian definition in a business context and to recommend its adoption by accountants. Solomon (1962) revised Alexander's work and created the impression that Hicks' analysis had stopped at the central meaning of income and in particular at the point of establishing his ex ante notion of income. 
Such an interpretation of Hicks'work coupled with the worsening inflationary climate in post World War I Europe led to consideration of alternatives to the reporting of income based on historical costs. Edwards and Bell (1961) brought together the economic and accounting views in a comprehensive theory of business income. They presented a contingency view of income where no single concept of income was useful for all possible situations. Even though E\&B were not the first to introduce the notion that assets be stated according to current or anticipated replacement or reproduction prices, their work came to be recognized as a benchmark and has since been quoted extensively as a "theoretical authority" on the subject (Clarke 1982, 298).

The Edwards \& Bell model was originally formulated as a theory of measurement of income that fundamentally advocated the use of specific prices of the assets as a means of dichotomizing the income into holding gains and current operating profits. Accounting for inflationary effects was not one of the major thrusts in the original argument for replacement cost accounting. However, E\&B (1961, 233-269) did address the issue and illustrated how general price level changes could be incorporated into the replace cost accounting system they proposed. As inflationary pressures in the American economy grew and the debate on measurement of accounting income became focused on depicting the impact of inflation on financial statements of an enterprise, the procedures developed by the two authors also found their way into some early professional prescriptions on accounting for prices level changes. In particular, the exposure draft on changing prices issued by FASB (FASB 1978A, par. 26) not only incorporated notions of profit calculations roughly in accord with E\&B's computation of current operating profit but also introduced realizable holding gains in the income statement.

Criticism of the E\&B model was quite widespread among the professional accounting bodies to oppose inclusion of realizable holding gains in the income statement and to insist on crediting such gains to an account in the capital structure (Clarke 1982, 304). When No. 33 was finally issued in 1979, the provision for including realizable holding gains in the income statement was omitted. The FASB decided that enterprises should report the increase or decrease in current cost amounts separate from the income from continuing operations (FASB 1979, par. 136 and 143). The FASB also did not provide definitive recommendations on important matters such as adjustment for catch-up depreciation, holding gains, and gearing adjustments that were advocated by some proponents of current cost accounting.

Due to the experimental nature of SFAS 33, no attempt was made to replace historical cost accounting which was recognized as a satisfactory, reliable, and useful basis of financial reporting (FASB 1979, par. 107). The statement did include a detailed discussion of the usefulness of the concepts of current costs (par. 116-144) and historical cost/constant dollar accounting (par. 145-155) and it did signal a 
limited incorporation of alternative income measurement theories into accounting practice, but its main focus remained on the recognition of the effects of changing prices (par. 92). Furthermore, the normative tone of SFAC No. 1 issued earlier and indications that the later parts of the framework would address important issues related to financial reporting [such as the selection of attributes to be measured, the scale of measurement, concept of capital maintenance etc.] did give the impression of some impending change in the prevailing basis of financial reporting (Walton 1984, 126). But the FASB eventually chose to merely list current practices in SFAC No. 5 and stated without much discussion or explanation that such practices would continue (FASB 1984, par. 91).

The FASB's position with respect to the continuation of current practice for reporting enterprise income, as stated in SFAC No. 1, was based on the argument that accrual accounting provided measures of earnings rather than evaluations of management's performance, estimates of earning power, prediction of earnings, assessment of risk, or confirmations or rejections of predictions or assessments (FASB 1978, par. 48). Under this rationale, supplementary disclosures were required under SFAS. 33 (FASB 1979, par. 108-114) on an experimental basis.

FASB did not find any evidence of the use of this data by majority of the users and acknowledged in No. 89 that No. 33 disclosures did not achieve the costbenefit relationship that had been anticipated for them (FASB 1986, par. 117). Consequently, after a long period of experimentation, the FASB decided to eliminate supplementary disclosures based on historical cost/constant dollars (FASB 1984A) and simply encouraged current cost disclosures (FASB 1986, par. 1). The rationale of this abandonment of a theoretically justified measure merely on a perceived nonachieved cost-benefit relationship still remains a big question. It is obvious that the FASB changed its view of benefit from theoretical propriety to some monetary measure to be compared with the cost of implementing the standard.

The FASB shifted its attention to other issues that would ostensibly streamline financial reporting under a consistent theoretical framework. Since the very early days, the SEC strongly favored the all-inclusive approach, however, the Committee on Accounting Procedure of the American Institute of Accountants generally favored an approach that included in income of the period only the effects of normal recurring operations. Eventually in 1966, however, the AICPA's Accounting Principles Board (APB), the committee's successor, largely adopted the all-inclusive concept in several opinions that it issued. It took three decades to require income disclosure using the all-inclusive with some exceptions that included foreign currency translations, accounting for futures contracts, employers' accounting for pensions, and accounting for certain investments in debt and equity securities.. It was in 1997 that SFAS 130 eliminated the exceptions to the application of the all inclusive requiring disclosure of net income and other comprehensive income as 
components of comprehensive income. The most common items included in other comprehensive income are foreign currency translation adjustment, minimum pension liability adjustments, and unrealized gains or losses on available-for-sale securities. FASB and the IASB have now decided that the financial statement presentation project should not alter existing standards relating to what items are recognized outside of profit or loss. Because of that stance, existing guidance remains unchanged on presentation of other comprehensive income items in a statement of comprehensive income and on the recycling mechanism. An entity should present a stand-alone statement of comprehensive income with other comprehensive income (OCI) items presented in a separate section. Within that OCI section an entity should indicate, parenthetically or otherwise, which category operating, investing or financing.

Dhaliwal et al. (1999) report that there is no support for the claim that comprehensive income is a better measure of firm permance than net income. In their study they found that with the exception of financial firms, there was no evidence that comprehensive income was more strongly associated with returns/market value or better predicts future cash flows/income than net income. The only component of comprehensive income that improved the association between income and returns was the marketable securities adjustment. The results of their study also raised questions about the appropriateness of items included in SFAS 130 comprehensive income as well as the need for mandating uniform comprehensive income disclosures for all industries.

\section{THE EFFECT OF INCOME TAX REGULATION}

Income tax laws also contributed to a widening of the gap between operational facility and usefulness of income. Since the incidence of income tax was to be on income and not on wealth, it was not feasible to assess taxes on the basis of annual balance sheet evaluation. An objective and verifiable method was to be found. Thus, it became necessary to abandon the concept of profit as increase in assets in favor of a transaction-based measure of income. Influence of income tax regulation is evident in the use of the term "net income" as opposed to the term "net profit" used elsewhere in financial reporting and acceptance of LIFO as one of the alternative methods of inventory valuation. Similarly, the use of accelerated depreciation methods became "generally accepted" in accounting practice although such liberalization of tax depreciation rules was primarily designed to stimulate the economy and not to arrive at a more realistic measure of income.

As Chatfield $(1977,209)$ points out, in all of these cases first the method was permitted under tax regulations then a supporting theory was developed to justify its use in accounting practice. However, since there was no real theory of 
income in tax law, it relied on accounting to provide one. But accounting itself lacked an agreed upon theory of income. The net result was a circular process of reasoning and theory development which came under heavy criticism and led to efforts to decouple accounting practice from the influence of tax regulations. Perhaps the most profound and lasting influence of income tax inspired reasoning came about when the Internal Revenue Code was amended towards the end of 1930's to permit income averaging through the device of loss carry-backs and carry-forwards. Furthermore, accounting for income taxes became a significant reporting issue when the Internal Revenue Code in the US permitted companies to depreciate the cost of emergency facilities considered essential to the war effort over a period of 60 months (Rayburn 1986, 89).

These developments resulted in added pressures to find a "proper" treatment of income taxes on the financial statements. The solution was found in treating income tax as an item of expense and to apply the matching concept in its reporting. The first authoritative pronouncement requiring income taxes to be regarded as expense was made in Accounting Research Bulletin [ARB] No. 43 (AICPA 1961) under which recognition of income tax expense was limited to the actual amount paid by the business entity.

ARB No. 44 (AICPA 1961) went a step further in response to increased pressure by business circles for inter-period allocation of taxes as a result of higher income having to be reported because of accelerated depreciation claimed on income tax returns. Under this pronouncement, it became necessary to take into consideration the differences in income tax calculated on the basis of expenses/revenues recognized under tax rules and under the accounting principle of matching, giving rise to a debit or credit balance on the asset or liability side of the balance sheet.

\section{INCONSISTENCIES AND CONTROVERSIES}

It is evident from the foregoing that the practice of financial reporting in the US has been a confusing mixture of approaches drawn from myriad perspectives and has therefore has been a topic of severe criticism for several years (de Mesa, 2005). This is because a significant number of practitioners and academics have held the view that in a society that is committed to democratic principles, the right to make rules depends ultimately on the acceptance of the ruled. Thus the term Generally Accepted Accounting Principles, which originally implied acceptance by only the accounting practitioners came to imply acceptance by a wider group claiming adverse consequences. As Moore (2009) points out, accounting standard-setting bodies espouse the usefulness of a consistent conceptual framework, and have derived multiple frameworks in the last century; yet none of them seem to last. One reason behind the failure of the accounting profession to settle on a set of guiding 
principle is the desire to make the standards acceptable to all the affected parties. ${ }^{2}$ Consequently efforts to formulate accounting standards based on a cogent theory of accounting in the US have not been very successful.

Accounting standards have neither yet come up with an undisputed measure of decision usefulness, nor with a satisfying method to rank competing measurement concepts, such as fair value or historical cost. The calculus of double entry book keeping was originally meant to ensure that transactions have been accurately recorded and the results of past transactions are faithfully presented in the financial statements. If indeed accounting statements were to serve the needs of diverse groups of users, then consideration must have been given to alternative ways of recording and reporting financial data, such as Triple Entry Bookkeeping (Ijiri 1986) and disarticulation of the income statement and the balance sheet. Articulation of the income statement and the balancer sheet has created the insoluble dilemma of choosing either the income statement or the balance sheet as the focus of emphasis.

Some inherent problems with accounting mrasurements are also worth noting. Numbers shown in financial statements are an odd combination of nominal, ordinal, anf ratio scale, which makes valid comparisons an impossibility. Furthemore, to date no consensus has been reached on available measurement approaches, such as cost basis, replacement cost, realizable value, and discounted cash flow Also, the issue of defining the concept of income is still outstanding in spite of sustained efforts by FASB since its establishment. There has been a long history of transaction based income determination that the FASB and IASB are trying to reverse by adopting the asset/liability or the wealth based view of income.

Transaction based income reflects the result of arm's length transactions that occur between the business and other entities. Under the asset/liabilty approach increases or decreases in income arise from changes in the underlying value of assets or liabilities held by the business entity without an exchange transaction. These two approaches affect the income statement and the balance sheet differently (Moore 2009 pp. 328 -30). Under the transaction based approach, matching of revenues and expenses was the governing principle for income statement disclosure and the resultant effect of the transaction was reflected on the balance sheet without much regard to propriety of valuation. The situation is reversed in the asset/liability approach where proper valuation of assets and liability is the priority and reported income is the resultant effect on reported income.

The reversion to the asset/liability approach started with the FASB's financial concepts project that identified present and future investors as the primary users of financial reports and declared usefulness for investment decision as the

${ }^{2}$ See Horngren (1973), May and Sundem (1976) for examples of this point of view. 
ultimate goal to be served by such reports. Hence, the focus of financial accounting and reporting standards drifted away from stewardship. Although initially stewardship and decision usefulness were recognized as the two main objectives of financial reporting, recent developments suggest that the distinction between the two objectives has disappeared. Both the FASB and IASB agree that stewardship or accountability should not be a separate objective of financial reporting by business entities in the converged conceptual framework (IASB 2005 para. 24). One of the most perplexing issues to have haunted accounting theorists is the unquestioned acceptance of income taxes as expense and the need to allocate it between periods. Even exploratory research such as Accounting Research Study No. 9 shied away from confronting the main issue

"The study does answer fundamental questions about the nature of the income tax and the validity of the concept of income tax allocation. Whether income taxes are conceptually expenses or distribution of income has not been resolved by the profession (Black 1966, vii)."

Although accounting for income taxes has been criticized by the leading accounting authors ${ }^{3}$, the FASB and its predecessor bodies have chosen to ignore the fundamental objection to treat income tax as an expense. Many noted writers such as Moonitz (1957) also argued in favor of treating income taxes as an expense on the ground that a dollar spent on income taxes was no different than a dollar spent on wages in terms their impact on interest of those for whom financial statements were prepared. Similarly, Hendricksen in his book on accounting theory (1977 pp. 467) argued that income taxes represent payment to the government for services rendered to the corporation. He also pointed out that income taxes, like franchise taxes, are associated with the right to conduct business.

No arguments against the expense would seem convincing if there is an arbitrary pre-disposition to treating income taxes as expense. But the substantive argument can be discussed on rational grounds. First, incurrence of expenses is never contingent upon the business reporting profit. It is universally recognized that the purpose of tax laws is the raising of public revenues in order to implement the socioeconomic policies of the government and to provide encouragement for general industrial development, provision of national defense etc. Even if one assumed that income taxes were payments for services received from the government that could somehow be specifically determined the justification for recognizing income taxes as expense does not follow because these services are available to businesses, other groups, and individuals who have no earned taxable income.

\footnotetext{
${ }^{3}$ See Blough, 1955; Moonitz, 1957; Hill, 1957; Li, 1961; Drinkwatwer \& Edwards, 1965; Chambers, 1968; Hawkins, 1968; Barton, 1970 Nair \& Weygandt, 1981; and Vulkan \& Rue, 1985 for these early criticisms.
} 
If it is held that court decisions rather than arguments based on accounting theory are the governing factor, it becomes pointless to pursue the matter any further. However, as Walgenback (1959) correctly (but in a different context) pointed out, decisions in tax cases are not germane to deciding issues of importance in accounting theory. In matters relating to fundamental issues of recognition and reporting the pertinent law is the law of disclosure. Although courts have ruled income tax to be an excise tax on the right to earn income (Pollock vs Farmer's Loan and Trust cited in Drinkwater and Edwards, 1965 p. 580), it does not automatically mean that the accounting treatment for the two types of taxes should be the same. As Chambers (1968 p. 105) points out, companies in loss have the right to earn but pay no taxes. A tax that varies with the result of exercising a right cannot be a tax on the right.

Some have argued that income tax has the same impact on the interest of the shareholders as other expenses in terms of distributable income and future cash flows. However, this does not support the treatment of income taxes as expense either. Payment of preferred dividend or retirement of debts has the same impact on the interest of shareholders. As a matter of fact in such cases the amount and timing of the reduction in cash flow is known with much greater degree of certainty.

FASB made another attempt at tackling the criticism and confusion about the tax allocation and issued SFAS 96 (FASB 1987). This time the FASB switched the emphasis from matching of revenues and expenses to the asset/liability method moving the focus of tax accounting from the income statement to the balance sheet. Under this approach, valuation of current and non-current deferred tax assets or liabilities determines the income statement amounts. Implementation of the standard was delayed because of stiff opposition to the standard. SFAS109 (FASB 1992) was issued to bring closure to accounting and financial reporting controversies concerning deferred taxes. The companies were required to use the asset liability approach and the current tax rate to accumulate the deferred assets and liabilities that resulted when the financial accounting and tax accounting bases of their assets and liabilities diverged.

Cooley, Rue, and Allen (2004 p. 17) made the following forceful criticisms against the asset/liability approach to resolve the controversies about income tax accounting:

1) SFAS 109 indicates that individual temporary differences become taxable when the related liability is settled. However, the characteristic of a liability resulting from depreciating an individual asset using different depreciation methods are present only if the temporary difference between taxable and financial statement income that would result in future recovery of taxes if there is taxable income in the future. Since there is no surety that there will be future taxable income and if there is no taxable income or a loss in the future, there is no future economic sacrifice. 
Recognition of liability is warranted only if the depreciable asset is not held to the end of its useful life.

2) Since there is no explicit or implicit contract between the business entity and the taxing authority, there is no likelihood that the government has a claim to the entity's assets for the deferred tax liability.

3) According to SFAC No. 6, future sacrifices are a result of past transactions or events. While depreciation is described as an internal event (FASB 1992 par. 138), temporary differences between taxable and financial statement income are not caused by the event of depreciation. The differences occur because of the use of alternative methods of depreciation and cannot be attributed to past transactions.

\section{CONCLUDING REMARKS}

The foregoing are but a few problem areas that need to be addressed and remedied by the FASB and IASB. Many, if not all the problems are the result of deliberate accommodation of lobbyists and other pressure groups. Ever since the beginning of standard setting process in the US, the debate about accounting standards has been in the political arena. The advocates for such politicization of accounting have not been confined to the pressure groups. Very prominent academic writers such as Horngren (1973), May and Sundem (1976), and Hawkins (1975) have strongly endorsed the need for political considerations to enter into the formulation of accounting standards.

It is true that accounting standards invariably have economic impact and accounting standards are needed mainly in areas where there is controversy. It is therefore natural that some group of people will find the standard to less favorable. But although information has an effect on human behavior, it should be as neutral as possible. It cannot be neutral or reliable if it is selected for the purpose of producing some chosen effect on human behavior. Accounting is financial mapmaking and a map is not judged by the behavior it elicits (Solomon 1973, p. 36).

Convergence with, or adoption of, International Financial Reporting Standards may also face opposition because of pressure from lobbyists, politicians and other interest groups is now inextricably embedded in the standard setting process in the US and other European countries. Professionals and academicians in emerging economies need to play the important role of advocating a course of theoretical propriety rather than political expediency because such pressure groups have not yet had the opportunity to organize in their countries.

Finally 
Not all accounting issues can be solved with better rules and more consistent conceptual frameworks. Allocation and boundary problems can be alleviated only by having users who are sophisticated enough to understand and distinguish between those elements of accounting reports that are objective and those that are arbitrary by their very nature. The accounting profession needs to consider why we feel compelled to change our rules and frameworks in response to each and every criticism while attorneys and doctors do not. Physicians and hospitals are not shy about making patients sign waivers of responsibility that specifically list all kinds of risks and negative outcomes. And the courts assume that legal clients not only can but should assist their attorneys in making decisions on legal strategy. In contrast, tax franchises run advertisements promising they can find "errors" that other accountants missed, reinforcing the popular idea that there is only one right answer. The accounting profession seems trapped in a cycle of constantly revising their rules and concepts. We go from method A, to method B, and eventually back to method $\mathrm{A}$ in reaction to a constant barrage of political crises. Perhaps it is time we seriously asked ourselves, "Does the accounting profession project an image of having correct answers because it is a weak profession, or do accountants have weak professional standing because they do not have the courage to admit publicly the inherent paradoxes and limitations of their craft?" 또

\section{REFERENCES}

Alexander, S. S. (1950). "Income Measurement in A Dynamic Economy". In Five Monographs on Business Income. New York: AIA.

American Institute of Certified Public Accountants. (1961). Accounting Research and Terminology Bulletins. New York: AICPA.

Barton, A. D. (1970). "Company Income Tax and Inter-period Allocation". Abacus. (September), pp. 3-24.

Belkaoui, A. (1981). Accounting Theory. New York: Harcourt Brace Jovanovich Inc.

Black, H. A. (1966). Accounting Research Study 9: Interperiod Allocation of Corporate Income Taxes. New York: American Institute of Certified Public Accountants

Blough, C. G. (1955). "Some Questions on Bulletin No. 44”.Journal of Accountancy (May), pp. 67-68. 
Brown, C. (1975, "The emergence of income reporting", International Journal of Accounting, Spring, Vol. 10 No. 1, pp. 85-107.

Chambers, R. J. (1968). "Tax Allocation and Financial Reporting”. Abacus, (December), pp. 99-123.

Chatfield, M. (1977). A History of Accounting Thought. Huntington, New York: Robert E. Krieger Company.

Cooley, R., Rue, J., and Allen, V. (2004). "Deferred Taxes Revisited". Journal of Business and Economics Research, Vol. 2(8), pp. 13-24.

de Mesa, Cheryl G. (2005). Financial Executive, July 1, 2005.

Dahliwal, D, Subramanyam, K., Trezevant, R. (1999). “Is Comprehensive Income Superior To Net Income As A Measure Of Firm Performance?" Journal of Accounting and Econmics, Vol. 26 (1-3), pp. 43-68.

Drinkwater, D. and Edwards, J. D. (1965). "The Nature of Taxes and the Matching Principle”. The Accounting Review. (July), pp. 579-582.

Edwards, E. O. and Bell, F. W. (1961). The Theory and Measurement of Business Income. Beklet: University of California Press.

Financial Accounting Standards Board [FASB] (1987). Statement of Financial Accounting Standards [SFAS] No. 96. Norwalk, CT: FASB.

Financial Accounting Standards Board [FASB] (1992). Statement of Financial Accounting Standards [SFAS] No. 109. Norwalk, CT: FASB.

Hawkins, D. F. (1968). "Controversial Accounting Changes". Harvard Business Review. (April), pp. 20-41.

Hendricksen, E. S. (1982). Accounting Theory (4 ${ }^{\text {th }}$ edition). Homewood, Illinois: Richard D. Irwin, Inc.

Horngren, C. T. (1973). "The Marketing of Accounting of Accounting Standards". Journal of Accountancy (October), pp. 51-66.

Hicks, J. R. (1946). Value and Capital. London: Oxford University Press 
Nair. R. D. and Weygandt, J. J. (1981) "Let's Fix Deferred Taxes". Journal of Accountancy (November), pp. 87-102.

Ijiri, Y. (1986). "A Framework of Triple Entry Bookkeeping”. The Accounting Review, (October), pp. 745-60.

International Accounting Standards Board. (2005). Agenda Paper 8A, October 19, 2005, Information for observers. Available at: htt//www. Iasb.org/current+projects/IASB+projects/conceptual+framework/meeting+summarie $\mathrm{s}+$ and+_observer+notes/october+2005.htm.

Langenderfer, H. (1987, "Accounting education's history - a 100-year search for identity", Journal of Accountancy, May, Vol. 163 No. 5, pp. 302-37.

Littleton, A. and Zimmerman, V. (1962). Accounting Theory: Continuity and Change, Prentice-Hall, Englewood Cliffs, NJ.

Marden, R. E. and Brackney, K. S. (2009). “Audit Risk and IFRS”., Vol. 79, Iss. 6; pp. 32-36.

May, R. G. and Sundem, G. L. (1976). "Research for Accounting Policy: An Overview." The Accounting Review (October) pp. 740-756.

Moonitz, M. (1957). “ 'Income taxes and financial statements." The Accounting Review, (April), pp. 175-83.

Moore, L. (2009). "Economic Reality and the Myth of the Bottom Line". Accounting Horizons (September), pp. 327-40.

Paton, W. and Littleton, A. (1940, An Introduction to Corporate Accounting Standards, American Accounting Association, Ann Arbor, MI.

Previts, G. (1981, "Some traditions of the American accounting discipline", in Buckley, J. (Ed.), The Impact of Accounting Research on Policy and Practice, Reston International Center, Reston, VA, pp. 115-40.

Rayburn, F. R. (1986). "A Chronological Review of the Authoritative Literature on Interperiod Allocation: 1940-1985". The Accounting Historian's Journal (fall), pp. 89-108. 
Ronen, J. (1998). "Financial Accounting Theory and Research" in Blackwell Encyclopedia Dictionary, Rashad Abdel Khalik (ed), Wiley-Blackwell, New York, pp. 146-149.

Solomons, D. (1962). "Income Measurement in A Dynamic Economy - A Revision of Article by Sidney Alexander". In Studies in Accounting Theory, edited by W. T. Baxter And S. Davidson. Homewood, ILL: Richard D. Irwin.

(1973). "The Politicization of Accounting". In Financial Accounting Theory: Issues and Controversies, edited by S. A. Zeff and T. F. Keller, McGrawHill Book Company, New York.

Vulkan, A. G. and Rue, J. C. (1985). "The Case Against Deferred Taxes". Management Accounting (March),, pp. 30-34.

Walgenback, P. H. (1959). "Legal Views of Corporate Income Tax Provision". The Accounting Review (October), pp. 579-83.

Walton, P. (1984). “One Step Forward, Two Steps Back”. Accountaancy (June), pp. 126-27.

Intelligence appears to be the thing that enables a man to get along without education. Education enables a man to get along without the use of his intelligence.

$\sim$ Albert Edward Wiggam 
I have been speaking of measures organizations can take. But ultimately any real change will be up to the individual himself, and this is why his education is so central to the problem. For he must look to his discontents with different eye. It has been said that dominance of the group is the wave of the future and that, lament it or not, he might as well accept it. But this is contemporaryism at its worst; things are not as they are because there is some good reason they are. Nor is the reverse true. It may one day prove true, as some prophets argue, that we are in a great and dismal tide of history that cannot be reversed, but if we accept the view we will only prove it.

The organization man is not in the grip of vast social forces about which It is impossible for him to do anything; the options are there, and with wisdom and foresight he can turn the future away from the dehumanized collective that so haunts our thoughts, he may not. But he can

He must fight the Organization. Not stupidly, or selfishly, for the defects of individual self-regard are no more to be venerated than the defects of co-operation. But fight he must, for the demands for his surrender are constant and powerful, and the more he has come to like the life of organization the more difficult he find it to resist thee demands, or even to recognize them. It is wretched, dispiriting advice to hold before him and society. There always is; there always must be. Ideology cannot wish it away; the peace of mind offered by organization remains a surrender, and no less so for being offered in benevolence. That is the problem.

William H. Whyte Jr. , The Organization Man, Pg 447-448 